\title{
The Use of Pocket Dictionary and Online Word-For-Word Translation on Reading Skill: An Experimental Study at Sman 4 Kota Bima Academic Year 2018/2019
}

\author{
Arma Dinarty \\ Postgraduate Student at the English Department, Mataram University, Indonesia
}

http://dx.doi.org/10.18415/ijmmu.v6i5.1221

\begin{abstract}
This research is aimed at comparing the impact of published pocket dictionary (PD) and online word-for- word (OWfW) translation on the students' reading skill. The study was conducted at the second year students of SMAN 4 Kota Bima in the academic year 2018/2019. The method used was experimental study wherein two classes of students were purposively selected as experimental samples. One class of 32 students (i.e. XI Science 1) served as the pocket dictionary group and one class of 32 students (i.e. XI Science 2) were selected as the word-for-word online translation group. Each group was taught three types of reading texts (i.e. narrative, argument, and procedure) obtained from pedagogic texts in the textbooks and authentic texts from other (non-textbook) sources. Pre-test and post-test were administered to each group prior to and after the treatment. The data was analyzed by using multiple t- test formula comparing multiple dimensions of the dictionary use and the reading skills. The study shows that both PD and OWfW translations were equally effective in assisting the students with the reading skills. PD translation is more effective for skimming skill useful for general comprehension of reading texts, OWfW translation is more effective for helping students scan for specific information in the texts. The paper also discusses opportunities and challenges facing the students in using the dictionary types.
\end{abstract}

Keywords: Dictionary; Translation; Reading Skill

\section{Introduction}

According to Kerap (2005) Dictionary is a reference book that a list of a words in one language which arranged alphabetically accompanied by the way to use the words.

A pocket dictionary is a dictionary published in form of a piece of paper which can be kept in a pocket that covers a list of essential words of a certain type of text that is going to be though in teaching reading. Its entry is arranged alphabetically and accompanied by examples based on the context, (Researcher). Dictionaries can be really helpful when you are reading because they help you find out the meaning of words you don't know. However using dictionary too much can cause problems with your reading skills (Englishlive.ef.com) Sitsanis (2017) Word for word online translation is the rendering of text from one language to another one word at the time with or without conveying the sense of the original whole. As we know Machine translations will not human translators, translation is one of the 
many ways people you can use to reach a massive audience from all walks of life and from every background who access the internet on a daily basis, translation is the only thing that will help you.

Harmer (2007), Reading is useful for language acquisition. Provided that students more or less understand what they read ,the more they read, the better they get at it.

According to Tarigan (1990) in Jaenal (2010) Reading is a process that is carried and used by readers who want to get the massage delivered by the author thought the medium of words or written language .

According to Wallace and Larsen (1987), reading is a multifaceted process, which can be described at various time and developmental stages as a thinking process. Reading ability is the main concern to able to read English textbooks, journals, and references, etc. Since most of textbooks and references are written in English, many student who find difficulties in comprehending them usually have their texts translated or extracted. It would be better if they can do it bye themselves, rather than depend on their English teachers.

Harmer( 1991) as quoted by Furqonul Azies stated that there are six skills that should be taken into account by the teachers in teaching reading to their students such as: predictive skill, find specific information, finding general idea, knowing function structure of text, finding the meaning through the context.

\section{Method}

Method is a technique or way that is used in holding on approach framework toward intended problem. Experimental method is used in this research to know the comparison between using pocket dictionary and word for word online translation in teaching reading skill at Second Year Student of SMAN 4 KOTA BIMA in Academic Year 2018/2019. The sample of the study will be purposively selected and the classes of XI-IPA1 (32 students) and XI-IPA2 (32 students) will be selected based on the following consideration: (a) they are one year behind national examination and permissible by the school to be used as samples, (b) the students are equal in motivation, diligence and gender distribution, and (c) the number of students in the classes of the sample are the same, that is, 32 students. The two classes of the population will be purposively selected as the experimental samples of the research. To obtain the data needed in the research, the writer will apply the following research instrument:

\section{Pre-test}

A pre-test will be administered before the treatments are implemented. The test will be a 25 item multiple-choice reading text.

\section{Treatment}

The first experimental group (i.e. XI-IPA1) will be treated with pocket dictionary when reading descriptive reading texts. The second experimental group (i.e.XI-IPA2) will use online dictionary when reading descriptive reading texts. 


\section{Post-test}

A post-test will be administered to both experimental groups after the treatments. The test will also consist of 25 multiple choice items and the texts will also be descriptive.

In gathering the data, the writer spent two weeks to do all the process of collecting the data: Starting from giving the pre-test, treatment and the last giving post-test. Pre-test was given earlier before the treatment begun and it was intended to know the students' reading skill. Then the writer gave the treatment for both first experimental group and second experimental group with different method of teaching. The topics during treatment process were the same for both. In the end of the research process, the writer organized a post-test which was aimed to find out the significance of the treatment given.

In scoring, the writer calculated the correct answers of 25 items of test which had been given. If the students answer 25 items correctly she/he gets 100 , as the highest score.

\section{Result}

\section{A. Reading Skill of the Pocket Dictionary Group}

The main focus of the study is on students reading skill prior and after the use of the two variables: manual and online dictionary. Below, reading skills of students treated with manual dictionaries are presented.

\section{Pretest}

In pre-test, the majority of the students reading skill fall within fairly good category (50\%) and only some of them fall within good $(38 \%)$ and very good $(3.13 \%)$.

Table 1 : Reading Skill of Pocket Dictionary Group in Pretest

\begin{tabular}{ccccc}
\hline No & Category & Limit & Frequency & $\%$ \\
\hline A & Excellent & $80-100$ & 0 & 0 \\
B & Very good & $66-79$ & 1 & 3.125 \\
C & Good & $56-65$ & 12 & 37.5 \\
D & Fairly good & $46-55$ & 16 & 50 \\
E & Fail & $0-45$ & 3 & 9.375 \\
\hline Total & & & 32 & \\
\hline
\end{tabular}

\section{Post Test}

In post-test, the majority of the students reading skill fall within very good category (78\%) and only some of them fall within good (13\%) and excellent (9\%).

Table 2 : Reading Skill of Pocket Dictionary Group in Posttest

\begin{tabular}{ccccc}
\hline No & Category & Limit & Frequency & $\%$ \\
\hline A & Excellent & $80-100$ & 3 & 9.375 \\
B & Very good & $66-79$ & 25 & 78.125 \\
C & Good & $56-65$ & 4 & 12.5 \\
D & Fairly good & $46-55$ & 0 & 0 \\
E & Fail & $0-45$ & 0 & 0 \\
\hline Total & & & 32 &
\end{tabular}




\section{Significance of Difference}

Whether the increase is significant or not, the pretest and the posttest scores will be measured by using internal t-test comparing the two sets of scores. Table 3 below presents the raw data and the calculation.

Table 3: Internal t-test for the pocket Dictionary Group

\begin{tabular}{|c|c|c|c|c|c|c|}
\hline NO & $\mathrm{X1}$ & dx & $\mathrm{X} 2$ & dy & $(d x)^{*}(d x 1)$ & $(d y)^{*}(d y)$ \\
\hline 1 & 44 & -9.5 & 72 & 0.75 & 90.25 & 0.5625 \\
\hline 2 & 52 & -1.5 & 72 & 0.75 & 2.25 & 0.5625 \\
\hline 3 & 52 & -1.5 & 76 & 4.75 & 2.25 & 22.5625 \\
\hline 4 & 56 & 2.5 & 72 & 0.75 & 6.25 & 0.5625 \\
\hline 5 & 52 & -1.5 & 84 & 12.75 & 2.25 & 162.5625 \\
\hline 6 & 56 & 2.5 & 80 & 8.75 & 6.25 & 76.5625 \\
\hline 7 & 56 & 2.5 & 68 & -3.25 & 6.25 & 10.5625 \\
\hline 8 & 68 & 14.5 & 68 & -3.25 & 210.25 & 10.5625 \\
\hline 9 & 56 & 2.5 & 76 & 4.75 & 6.25 & 22.5625 \\
\hline 10 & 60 & 6.5 & 72 & 0.75 & 42.25 & 0.5625 \\
\hline 11 & 60 & 6.5 & 72 & 0.75 & 42.25 & 0.5625 \\
\hline 12 & 52 & -1.5 & 76 & 4.75 & 2.25 & 22.5625 \\
\hline 13 & 52 & -1.5 & 68 & -3.25 & 2.25 & 10.5625 \\
\hline 14 & 56 & 2.5 & 72 & 0.75 & 6.25 & 0.5625 \\
\hline 15 & 52 & -1.5 & 68 & -3.25 & 2.25 & 10.5625 \\
\hline 16 & 56 & 2.5 & 72 & 0.75 & 6.25 & 0.5625 \\
\hline 17 & 52 & -1.5 & 76 & 4.75 & 2.25 & 22.5625 \\
\hline 18 & 48 & -5.5 & 60 & -11.25 & 30.25 & 126.5625 \\
\hline 19 & 64 & 10.5 & 80 & 8.75 & 110.25 & 76.5625 \\
\hline 20 & 48 & -5.5 & 76 & 4.75 & 30.25 & 22.5625 \\
\hline 21 & 48 & -5.5 & 68 & -3.25 & 30.25 & 10.5625 \\
\hline 22 & 56 & 2.5 & 72 & 0.75 & 6.25 & 0.5625 \\
\hline 23 & 40 & -13.5 & 68 & -3.25 & 182.25 & 10.5625 \\
\hline 24 & 52 & -1.5 & 68 & -3.25 & 2.25 & 10.5625 \\
\hline 25 & 52 & -1.5 & 76 & 4.75 & 2.25 & 22.5625 \\
\hline 26 & 52 & -1.5 & 56 & -15.25 & 2.25 & 232.5625 \\
\hline
\end{tabular}




\begin{tabular}{|c|c|c|c|c|c|c|}
\hline 27 & 60 & 6.5 & 76 & 4.75 & 42.25 & 22.5625 \\
\hline 28 & 52 & -1.5 & 60 & -11.25 & 2.25 & 126.5625 \\
\hline 29 & 52 & -1.5 & 68 & -3.25 & 2.25 & 10.5625 \\
\hline 30 & 56 & 2.5 & 64 & -7.25 & 6.25 & 52.5625 \\
\hline 31 & 52 & -1.5 & 68 & -3.25 & 2.25 & 10.5625 \\
\hline 32 & 48 & -5.5 & 76 & 4.75 & 30.25 & 22.5625 \\
\hline \multirow[t]{4}{*}{ Sum } & 1172 & 0 & 2280 & 0 & 920 & 1134 \\
\hline & Mean & 53.5 & & 71.25 & & \\
\hline & t-test & & & 0,54737 & & \\
\hline & $32+32)-2$ & & & 62 & & \\
\hline
\end{tabular}

With the $\mathrm{t}$-count equaling to 0,54737 is greater that the $\mathrm{t}$-table both at $95 \%$ and $99 \%$ and this indicates that there is no significant increase in the student reading skill before and after the treatment with pocket dictionary.

\section{B. Reading Skill of the Online Dictionary Group}

Below, reading skills of students treated with manual dictionaries are presented.

\section{Pretest}

In pre-test, the majority of the students reading skill fall within fairly good category (53\%) and only some of them fall within good (38\%) and very good (3\%).

Table 4 : Reading Skill of Online Dictionary in Pretest

\begin{tabular}{lllcl}
\hline No & Category & Limit & Frequency & $\%$ \\
\hline A & Excellent & $80-100$ & 0 & 0 \\
B & Very good & $66-79$ & 1 & 3.125 \\
& & & & \\
C & Good & $56-65$ & 12 & 37.5 \\
D & Fairly good & $46-55$ & 17 & 53.125 \\
E & Fail & $0-45$ & 2 & 6.25 \\
\hline Total & & & 32 & \\
\hline
\end{tabular}




\section{Posttest}

In post-test, the majority of the students reading skill fall within very good category (81\%) and only some of them fall within good (9\%) and excellent (9\%).

Table 5: Reading Skill of Online Dictionary in Pretest

\begin{tabular}{lllcl}
\hline No & Category & Limit & Frequency & $\%$ \\
\hline A & Excellent & $80-100$ & 3 & 9.375 \\
B & Very good & $66-79$ & 26 & 81.25 \\
C & Good & $56-65$ & 3 & 9.375 \\
D & Fairly good & $46-55$ & 0 & 0 \\
E & Fail & $0-45$ & 0 & 0 \\
\hline Total & & & 32 \\
\hline
\end{tabular}

\section{Significance of Difference}

Table 6 : Internal t-test for the Online Dictionary Group

\begin{tabular}{|c|c|c|c|c|c|c|}
\hline No & Y1 & $\mathrm{Y} 1$ & $\mathrm{Y} 2$ & $\mathrm{Y} 2$ & $\mathrm{Y} 1 * \mathrm{y} 1$ & $\mathrm{Y} 2 * \mathrm{y} 2$ \\
\hline 1 & 48 & -5 & 76 & 0.1 & 26.01 & 0.01 \\
\hline 2 & 56 & 3 & 80 & 4.1 & 8.41 & 16.81 \\
\hline 3 & 48 & -5 & 88 & 12.1 & 26.01 & 146.41 \\
\hline 4 & 52 & -1 & 80 & 4.1 & 1.21 & 16.81 \\
\hline 5 & 52 & -1 & 80 & 4.1 & 1.21 & 16.81 \\
\hline 6 & 52 & -1 & 78 & 2.1 & 1.21 & 4.41 \\
\hline 7 & 56 & 3 & 72 & -3.9 & 8.41 & 15.21 \\
\hline 8 & 64 & 11 & 80 & 4.1 & 118.81 & 16.81 \\
\hline 9 & 56 & 3 & 76 & 0.1 & 8.41 & 0.01 \\
\hline 10 & 56 & 3 & 80 & 4.1 & 8.41 & 16.81 \\
\hline 11 & 56 & 3 & 88 & 12.1 & 8.41 & 146.41 \\
\hline 12 & 52 & -1 & 80 & 4.1 & 1.21 & 16.81 \\
\hline 13 & 48 & -5 & 68 & -7.9 & 26.01 & 62.41 \\
\hline 14 & 56 & 3 & 76 & 0.1 & 8.41 & 0.01 \\
\hline 15 & 44 & -9 & 68 & -7.9 & 82.81 & 62.41 \\
\hline 16 & 52 & -1 & 68 & -7.9 & 1.21 & 62.41 \\
\hline 17 & 56 & 3 & 72 & -3.9 & 8.41 & 15.21 \\
\hline 18 & 52 & -1 & 64 & -11.9 & 1.21 & 141.61 \\
\hline 19 & 68 & 15 & 80 & 4.1 & 222.01 & 16.81 \\
\hline 20 & 52 & -1 & 68 & -7.9 & 1.21 & 62.41 \\
\hline 21 & 52 & -1 & 68 & -7.9 & 1.21 & 62.41 \\
\hline
\end{tabular}




\begin{tabular}{lllllll}
22 & 56 & 3 & 80 & 4.1 & 8.41 & 16.81 \\
23 & 56 & 3 & 68 & -7.9 & 8.41 & 62.41 \\
24 & 56 & 3 & 80 & 4.1 & 8.41 & 16.81 \\
25 & 48 & -5 & 80 & 4.1 & 26.01 & 16.81 \\
26 & 52 & -1 & 68 & -7.9 & 1.21 & 62.41 \\
27 & 56 & 3 & 84 & 8.1 & 8.41 & 65.61 \\
28 & 44 & -9 & 80 & 4.1 & 82.81 & 16.81 \\
29 & 48 & -5 & 84 & 8.1 & 26.01 & 65.61 \\
30 & 52 & -1 & 72 & -3.9 & 1.21 & 15.21 \\
31 & 56 & 3 & 80 & 4.1 & 8.41 & 16.81 \\
32 & 48 & -5 & 64 & -11.9 & 26.01 & 141.61 \\
\hline sum & 1700 & & 2430 & & $\mathbf{7 7 5 . 5 2}$ & $\mathbf{1 3 9 5 . 9}$ \\
Mean & 53.1 & & 75.9375 & & & \\
t-test & 4.875 & & & & &
\end{tabular}

With the t-count equaling to 4,875 is greater that the t-table both at $95 \%$ (2.000) and $99 \%$ (2.660) and this indicates that there is significant increase in the student reading skill before and after the treatment with Online dictionary.

\section{Comparison between the Use of Pocket and Online Dictionary}

The main question in the study is which of the two media for learning reading skills is more effective considering the fact that both are effective. In order to assess this significance, t-test was used and the calculation is presented below.

Table 7: Two Groups Comparison

\begin{tabular}{|c|c|c|c|c|c|c|c|c|c|c|c|}
\hline \multicolumn{3}{|c|}{ Pocket dictionary } & \multicolumn{3}{|c|}{ Online Dictionarty } & \multirow[b]{2}{*}{ DX } & \multirow[b]{2}{*}{ DY } & \multirow[b]{2}{*}{$\mathrm{dx}$} & \multirow[b]{2}{*}{ dy } & \multirow[b]{2}{*}{$d x * d x$} & \multirow[b]{2}{*}{$\mathrm{dy}^{*} \mathrm{dy}$} \\
\hline sample & $\mathrm{x} 1$ & $\mathrm{x} 2$ & sample & y1 & $\mathrm{y} 2$ & & & & & & \\
\hline 1 & 44 & 68 & 1 & 48 & 76 & 24 & 28 & 13 & 5.2 & 169 & 27.04 \\
\hline 2 & 52 & 72 & 2 & 56 & 80 & 20 & 24 & 9 & 1.2 & 81 & 1.44 \\
\hline 3 & 56 & 80 & 3 & 48 & 88 & 24 & 40 & 13 & 17.2 & 169 & 295.84 \\
\hline 4 & 60 & 76 & 4 & 52 & 80 & 16 & 28 & 5 & 5.2 & 25 & 27.04 \\
\hline 5 & 56 & 68 & 5 & 52 & 80 & 12 & 28 & 1 & 5.2 & 1 & 27.04 \\
\hline 6 & 56 & 68 & 6 & 52 & 78 & 12 & 26 & 1 & 3.2 & 1 & 10.24 \\
\hline 7 & 60 & 68 & 7 & 56 & 72 & 8 & 16 & -3 & -6.8 & 9 & 46.24 \\
\hline 8 & 64 & 76 & 8 & 64 & 80 & 12 & 16 & 1 & -6.8 & 1 & 46.24 \\
\hline 9 & 56 & 56 & 9 & 56 & 76 & 0 & 20 & -11 & -2.8 & 121 & 7.84 \\
\hline 10 & 60 & 72 & 10 & 56 & 80 & 12 & 24 & 1 & 1.2 & 1 & 1.44 \\
\hline & & & & & & & & & & 1021 & \\
\hline
\end{tabular}




\begin{tabular}{|c|c|c|c|c|c|c|c|c|c|c|c|}
\hline & 64 & 72 & 11 & 56 & 88 & 8 & 32 & -3 & 9.2 & 9 & 84.64 \\
\hline & 52 & 60 & 12 & 52 & 80 & 8 & 28 & -3 & 5.2 & 9 & 27.04 \\
\hline & 52 & 60 & 13 & 48 & 68 & 8 & 20 & -3 & -2.8 & 9 & 7.84 \\
\hline & 60 & 68 & 14 & 56 & 76 & 8 & 20 & -3 & -2.8 & 9 & 7.84 \\
\hline & 52 & 60 & 15 & 44 & 68 & 8 & 24 & -3 & 1.2 & 9 & 1.44 \\
\hline & 56 & 68 & 16 & 52 & 68 & 12 & 16 & 1 & -6.8 & 1 & 46.24 \\
\hline & 56 & 68 & 17 & 56 & 72 & 12 & 16 & 1 & -6.8 & 1 & 46.24 \\
\hline & 48 & 60 & 18 & 52 & 64 & 12 & 12 & 1 & -10.8 & 1 & 116.64 \\
\hline & 64 & 76 & 19 & 68 & 80 & 12 & 12 & 1 & -10.8 & 1 & 116.64 \\
\hline & 60 & 60 & 20 & 52 & 68 & 0 & 16 & -11 & -6.8 & 121 & 46.24 \\
\hline & 48 & 60 & 21 & 52 & 68 & 12 & 16 & 1 & -6.8 & 1 & 46.24 \\
\hline & 60 & 72 & 22 & 56 & 80 & 12 & 24 & 1 & 1.2 & 1 & 1.44 \\
\hline & 44 & 56 & 23 & 56 & 68 & 12 & 12 & 1 & -10.8 & 1 & 116.64 \\
\hline & 56 & 60 & 24 & 56 & 80 & 4 & 24 & -7 & 1.2 & 49 & 1.44 \\
\hline & 52 & 60 & 25 & 48 & 80 & 8 & 32 & -3 & 9.2 & 9 & 84.64 \\
\hline & 56 & 64 & 26 & 52 & 68 & 8 & 16 & -3 & -6.8 & 9 & 46.24 \\
\hline & 64 & 76 & 27 & 56 & 84 & 12 & 28 & 1 & 5.2 & 1 & 27.04 \\
\hline & 52 & 64 & 28 & 44 & 80 & 12 & 36 & 1 & 13.2 & 1 & 174.24 \\
\hline & 56 & 64 & 29 & 48 & 84 & 8 & 36 & -3 & 13.2 & 9 & 174.24 \\
\hline & 56 & 64 & 30 & 52 & 72 & 8 & 20 & -3 & -2.8 & 9 & 7.84 \\
\hline & 60 & 76 & 31 & 56 & 80 & 16 & 24 & 5 & 1.2 & 25 & 1.44 \\
\hline & 56 & 64 & 32 & 48 & 64 & 8 & 16 & -3 & -6.8 & 9 & 46.24 \\
\hline & 1788 & 2136 & & 1700 & 2430 & 348 & 730 & & & 872 & 1718.9 \\
\hline Mean & & & & 53.125 & 75.9375 & 11 & 22.8 & & & & \\
\hline Df & \multicolumn{11}{|l|}{60} \\
\hline t-test & \multicolumn{11}{|l|}{7,387} \\
\hline
\end{tabular}

With the mean deviation scores of each group $(11 \& 22.8)$ and the degree of freedom $(\mathrm{Nx}+\mathrm{Ny})-$ 2 equals to 62 , a t-test score equaling to 7,363 and t-table values of 2.00 and 2.660 both at the significance level of $95 \%$ and $99 \%$. Thus the null hypothesis is rejected.

Table 8 : Comparison of t-test and t-table

\begin{tabular}{cccc}
\hline t-test & \multicolumn{3}{c}{ t-table } \\
7.363 & $\mathrm{df}$ & 0.05 & 0.01 \\
& 62 & 2.00 & 2.660 \\
\hline
\end{tabular}

The study can now conclude that there is a significant difference on the effect of the use of online dictionary and the use of manual dictionary on the students reading skills in which online dictionary is a better media for helping students in increasing reading skills. 


\section{Comparison of the Sub-skills of Reading Skill}

\section{a. The Pocket Dictionary Group}

Identifying internal improvement in the PDG, we need to compare pre-test and post-test scores on each sub-skill by the pDG students and these data are presented in Table 4.8 but summarized in Table 9 .

Table 9: Internal t-test on Pocket Dictionary Group

\begin{tabular}{|c|c|c|c|c|c|c|c|c|c|c|}
\hline \multirow{5}{*}{$\begin{array}{l}\text { Sum } \\
\text { Mean } \\
\text { t-test }\end{array}$} & \multicolumn{5}{|c|}{ Dx1 } & \multicolumn{5}{|c|}{$(\mathrm{Dx} 1)^{*}(\mathrm{Dx} 2)$} \\
\hline & A & B & $\mathrm{C}$ & D & $\mathrm{E}$ & A & B & $\mathrm{C}$ & $\mathrm{D}$ & $\mathrm{E}$ \\
\hline & 620 & 220 & 300 & 380 & 220 & 1192 & 3687.52 & 3187.52 & 4688 & 5479.52 \\
\hline & 19 & 6.9 & 9.4 & 12 & 6.9 & & & & & \\
\hline & & & & & & 1.55 & 2.73 & 2.54 & 3.07 & 3.33 \\
\hline \multirow{2}{*}{ Significance } & & & $95 \%$ & & & & & 1.697 & & \\
\hline & & & $99 \%$ & & & & & 2.457 & & \\
\hline
\end{tabular}

Table 9 indicates that t-counts for A (Predictive skill), B (Main-Idea Finding Skill), C (SpecificInformation for Finding Skill), D (Discursive Skill) and E (Contextual Meaning Identifying Skill) are respectively $1.55,2.73,2.54,3.07$, and 3.33 . When compared with t-values at $.05(95 \%)$ and $.01(99 \%)$ which are 1.697 and 2.457, only in predictive skill that the null hypothesis is not rejected. Thus, the use of manual dictionary has increased the students' skills in predicting meanings (A) identifying main ideas (B), specific information (C), the structure of the text (D) and guessing meaning from contexts (E).

\section{b. The Online Dictionary Group}

Identifying internal improvement in the ODG, we need to compare pre-test and post-test scores on each sub-skill by the ODG students and these data are presented but summarized in Table 4.10 below.

Table 10: Internal t-test on ODG

\begin{tabular}{|c|c|c|c|c|c|c|c|c|c|c|}
\hline & \multicolumn{5}{|c|}{ Dx1 } & \multicolumn{5}{|c|}{$(\mathrm{Dx} 1)^{*}(\mathrm{Dx} 2)$} \\
\hline & A & B & $\mathrm{C}$ & $\mathrm{D}$ & E & A & B & $\mathrm{C}$ & D & $\mathrm{E}$ \\
\hline Sum & 960 & 920 & 700 & 780 & 340 & 7200 & 12752 & 6688 & 10192 & 113713 \\
\hline Mean & 30 & 29 & 22 & 24 & 1 & A & B & $\mathrm{C}$ & D & E \\
\hline t-test & & & & & & 3.81 & 5.07 & 3.67 & 4.53 & 15.14 \\
\hline \multirow{2}{*}{ Significance } & \multicolumn{5}{|c|}{$95 \%$} & \multicolumn{5}{|c|}{1.697} \\
\hline & \multicolumn{5}{|c|}{$99 \%$} & \multicolumn{5}{|c|}{2.457} \\
\hline
\end{tabular}

Table 10 indicates that t-counts for A (Predictive skill), B (Main-Idea Finding Skill), C (SpecificInformation for Finding Skill), D (Discursive Skill) and E (Contextual Meaning Identifying Skill) are respectively $3.81,5.07,3,67,4.53$, and 15.14 . When compared with t-values at $.05(95 \%)$ and $.01(99 \%)$ which are 1.697 and 2.457, all t-counts are above the the t-values. Thus, the use of online dictionary has increased the students' skills in predicting meanings (A), identifying main ideas (B), specific information (C), the structure of the text (D) and guessing meaning from contexts. 


\section{Discussion}

The study found that in the pre-test the majority of the students' reading skills were fairly good but after the treatment there was a sharp increase in the reading skills the majority being at very good level. This is expected as with the use of dictionaries students might get help in correctly identifying meanings. As Hayati,(2005) mentions, with the help of dictionaries students might get help that they need when learning a new language and with these helps they can do reading tasks with ease. Similarly, Bejoint and Moulin (1987), with bilingual dictionaries the students are quick to consult meanings of new lexical items which might compolicate reading tasks..

The study also found that that there is significant increase in the student reading skill before and after the treatment with the pocket dictionary. The study also found that the use of manual dictionary has increased the students' skills in identifying main ideas, specific information, the structure of the text, and guessing meaning from contexts. However, it fails to increase the students ability in predicting meanings based on reading contexts. Perhaps, predicting meanings require more contexts which pocket or manual dictionaries might fail to provide (Kerap, 200),

The study also found that that there is significant increase in the student reading skill before and after the treatment with the word for word online translation with online dictionaries. The study also found that the use of online dictionary has increased the students' skills predicting meanings based on reading contexts, identifying main ideas, specific information, the structure of the text, and guessing meaning from contexts.

With t-test, the study founds significant increases in Predictive skill, Main-Idea Finding Skill, Specific-Information for Finding Skill, Discursive Skill and Contextual Meaning Identifying Skill. Thus, the use of online dictionary has increased all the reading skills. Perhaps, as Hornby (1996) argues, the flexibility of the online dictionary has enable the students to look for more clues on word meanings and thus text meanings enabling them to guess meaning more correctly.

The study also found a significant difference in the increase of reading skill in both groups. The study concludes that there is a significant difference on the effect of the use of online dictionary and the use of manual dictionary on the students reading skills in which online dictionary is a better media for helping students in increasing reading skills.

\section{Conclusion}

Based on the analyses in the previous chapter, we can conclude that The majority of the students' reading skills in pretests were fairly good but after treatment there was a sharp increase in the reading skills the majority were very good, the use of manual dictionary has increased the students' skills in identifying main ideas, specific information, the structure of the text, and guessing meaning from contexts. However, it fails to increase the students' ability in predicting meanings based on reading contexts.

The use of online dictionary has increased the students' skills predicting meanings based on reading contexts, identifying main ideas, specific information, the structure of the text, and guessing meaning from contexts. Though equally significant, the use of online dictionary is more effective than manual or pocket dictionary in increasing reading skills. Thus, online dictionary is a better media for helping students in increasing reading skills. 


\section{Suggestion}

The findings above bring the following pedagogical implications:

1. Teaching readings or other English language skills, students and teachers have to equip themselves with either pocket or online dictionaries.

2. Teaching reading, teachers should enable students to explore words independently using pocket or online dictionaries.

3. Teachers should encourage learners with skills and experience in using dictionaries for learning English in general or reading in particular.

4. While the study focuses on manual and online dictionaries, the use of other forms of dictionaries (such as table dictionaries, classroom dictionaries, or student-built dictionaries) should be encouraged and in need of further studies.

This work is part of an MA thesis, supervised by DR. Muhammad Amin, M.TESOL and DR. Amrullah, M.Pd

\section{References}

Azies, Furqonul, et.all.,1996, Pengajaran Bahasa Kemunikatif, Teori dan Praktik, Bandung, PT Remaja Doskara.

Arikunto, Suharsimi. 1997. Prosedur Penelitian Suatu Pendekatan Praktek. Jakarta: PT Rineka Cipta.

Harmer, Jeremy. 2007 . How to teach English. Cina : Pearson Longman.

Hornby, AS. 2006. Oxford Advanced Learner's Dictionary of Current English. London: Oxford University Press.

Harmer, Jeremi. 2001.The Practice of English Language Teaching. Third edition. Longman Pearson Education Limited.

Harmer. 2007. The Practice of English Language Teaching. Fourth Edition. Malaysia : Longman Pearson Education Limited.

Jaenal. 2010. Improving student's reading skill using group discussion. On the first grade of senior high school. UNISRI Jakarta. 
John W. Creswell.2008. Research design: Qualitative, quantitative, and mixed methods approaches: United Stated of America.

Lado, R. 1997. Language Testing. London: Longman Group.

Richard, Jack C and Willy A Renandya. 2002. Methodology in Language Teaching : An Anthology of Current Practice. Cambridge University.

Wallace, M. J. and Larsen, F.D.1987. Technique and Principles in Teaching Reading. Oxford : Oxford University Press.

\section{Copyrights}

Copyright for this article is retained by the author(s), with first publication rights granted to the journal.

This is an open-access article distributed under the terms and conditions of the Creative Commons Attribution license (http://creativecommons.org/licenses/by/4.0/). 